\title{
Inclusion of sainfoin (Onobrychis viciifolia) silage in dairy cow rations affects nutrient digestibility, nitrogen utilization, energy balance, and methane emissions
}

\author{
N. T. Huyen, ${ }^{* 1,2}$ O. Desrues, $†$ S. J. J. Alferink, ${ }^{*}$ T. Zandstra, ${ }^{*}$ M. W. A. Verstegen, ${ }^{*}$ W. H. Hendriks, ${ }^{*} \ddagger$ \\ and W. F. Pellikaan* \\ *Animal Nutrition Group, Wageningen University, PO Box 338, $6700 \mathrm{AH}$ Wageningen, the Netherlands \\ †Parasitology and Aquatic Diseases, University of Copenhagen, 1870 Frederiksberg C, Denmark \\ ‡Department of Farm Animal Health, Utrecht University, PO Box 80.163, 3508 TD Utrecht, the Netherlands
}

\begin{abstract}
Sainfoin (Onobrychis viciifolia) is a tanniniferous legume forage that has potential nutritional and health benefits preventing bloating, reducing nematode larval establishment, improving $\mathrm{N}$ utilization, and reducing greenhouse gas emissions. However, the use of sainfoin as a fodder crop in dairy cow rations in northwestern Europe is still relatively unknown. The objective of this study was to evaluate the effect of sainfoin silage on nutrient digestibility, animal performance, energy and $\mathrm{N}$ utilization, and $\mathrm{CH}_{4}$ production. Six rumencannulated, lactating dairy cows with a metabolic body weight $\left(\mathrm{BW}^{0.75}\right)$ of $132.5 \pm 3.6 \mathrm{~kg}$ were randomly assigned to either a control (CON) or a sainfoin (SAIN)based diet over 2 experimental periods of $25 \mathrm{~d}$ each in a crossover design. The CON diet was a mixture of grass silage, corn silage, concentrate, and linseed. In the SAIN diet, $50 \%$ of grass silage dry matter (DM) of the CON diet was exchanged for sainfoin silage. The cows were adapted to $95 \%$ of ad libitum feed intake for a 21-d period before being housed in climate-controlled respiration chambers for $4 \mathrm{~d}$, during which time feed intake, apparent total-tract digestibility, $\mathrm{N}$ and energy balance, and $\mathrm{CH}_{4}$ production was determined. Data were analyzed using a mixed model procedure. Total daily DM, organic matter, and neutral detergent fiber intake did not differ between the 2 diets. The apparent digestibility of DM, organic matter, neutral detergent fiber, and acid detergent fiber were, respectively, 5.7, 4.0, 15.7, and $14.8 \%$ lower for the SAIN diet. Methane production per kilogram of DM intake was lowest for the SAIN diet, $\mathrm{CH}_{4}$ production as a percentage of gross
\end{abstract}

Received October 31, 2015.

Accepted January 7, 2016.

${ }^{1}$ Corresponding author: huyen.nguyen@wur.nl or nthuyencnts@ gmail.com

${ }^{2}$ Current address: Department of Animal Nutrition and Feed Technology, Vietnam National University of Agriculture, Trau Quy, Gia Lam, Hanoi, Vietnam. energy intake tended to be lower, and milk yield was greater for the SAIN diet. Nitrogen intake, N retention, and energy retained in body protein were greater for the SAIN than for the CON diet. Nitrogen retention as a percentage of $\mathrm{N}$ intake tended to be greater for the SAIN diet. These results suggest that inclusion of sainfoin silage in dairy cow rations reduces $\mathrm{CH}_{4}$ per kilogram of DM intake and nutrient digestibility. Moreover, sainfoin silage improves milk production and seems to redirect metabolism toward body protein accretion at the expense of body fat.

Key words: sainfoin silage, digestibility, methane production, nitrogen utilization

\section{INTRODUCTION}

Methane $\left(\mathrm{CH}_{4}\right)$ is the second most important gas involved in global warming, with $\mathrm{CH}_{4}$ from livestock accounting for $6.3 \%$ of the human-induced production of greenhouse gases when expressed in $\mathrm{CO}_{2}$-equivalents (Gerber et al., 2013). Among livestock, ruminants are the main contributors, accounting for $65 \%$ of emissions. Ruminants typically lose between 2 and $12 \%$ of their ingested energy as eructated $\mathrm{CH}_{4}$ (Johnson and Johnson, 1995). These energy losses are not only an environmental concern but also reduce efficiencies in ruminant production. Reducing the enteric $\mathrm{CH}_{4}$ emissions of cattle would lessen the impact of livestock production on the environment and potentially decrease the costs of production by increasing feed efficiency. A decrease in $\mathrm{CH}_{4}$ emissions from ruminants can be achieved by improving feed quality (Ominski et al., 2006), adding oils to the diet (Alexander et al., 2008; Castillejos et al., 2008), or including secondary compounds such as condensed tannins (CT) in the diets (Carulla et al., 2005; Waghorn, 2008).

Sainfoin (Onobrychis viciifolia) is a tanniniferous legume that is grown under different climatic conditions in Europe, Asia, and western North America, primarily in calcareous soils (Hayot Carbonero et al., 2011). Sainfoin can be grown as a pure stand or mixed with 
perennial ryegrass as companion crop (Moyer, 1985), and it is useful for grazing, hay-making, and for silage. Sainfoin is reported to support a similar animal performance compared with grass and grass-clover hay when offered as hay to dairy cows (Scharenberg et al., 2009). Additional ruminant health benefits of sainfoin include the prevention of bloat (McMahon et al., 1999) and parasitism (Hoste et al., 2015). These positive effects may be explained by the CT that are present in sainfoin (Hayot Carbonero et al., 2011). In addition, due to the $\mathrm{CT}$ in sainfoin (compared with alfalfa), $\mathrm{N}$ excretion is partially redirected from urine to feces in sheep and, therefore, could reduce ammonia $\left(\mathrm{NH}_{3}\right)$ volatilization from ruminant manure (Copani et al., 2015). Sainfoin $\mathrm{CT}$ have also been shown to reduce $\mathrm{CH}_{4}$ emissions in vitro (Hatew et al., 2015a,b). Limited data, however, are available on the effect of sainfoin on $\mathrm{CH}_{4}$ emission in vivo, and to the authors' knowledge, no data are available on the use of sainfoin silage in TMR typically fed to dairy cows. The hypothesis of this study was that inclusion of sainfoin silage at the expense of grass silage in a TMR for dairy cows would reduce $\mathrm{CH}_{4}$ emission, alter $\mathrm{N}$ metabolism, and affect milk production. Therefore, the objective of this study was to compare enteric $\mathrm{CH}_{4}$ emissions, diet digestibility, energy and protein utilization, and $\mathrm{N}$ excretions from dairy cows receiving TMR based on either sainfoin silage (a CT-containing forage) or grass silage (a CT-free forage).

\section{MATERIALS AND METHODS}

\section{Experimental Design}

The experiment was approved by the Institutional Animal Care and Use Committee of Wageningen University (Wageningen, the Netherlands) and executed in accordance with European Union directive 2010/63/ EU implemented by the Dutch legislation on the use of experimental animals. The experiment was conducted from February to April 2014 at the Carus Research Facilities of Wageningen University. The experiment followed a crossover design with 2 dietary treatments and 6 rumen-cannulated (Type 1C; Bar Diamond Inc., Parma, ID) lactating multiparous dairy cows with a mean \pm SD metabolic BW $\left(\mathbf{B W}^{0.75}\right)$ of $132.5 \pm 3.6 \mathrm{~kg}$, $214 \pm 72$ DIM, and an average milk production of 23.1 $\pm 2.8 \mathrm{~kg} / \mathrm{d}$ at the start of the experiment. Cows were paired based on parity and milk production; within pairs, cows were randomly assigned to receive either a grass and corn silage-based control (CON) diet or a sainfoin-grass and corn silage-based (SAIN) diet (Table 1) for an experimental period of $25 \mathrm{~d}$ (adaptation period from d 8-29 and subsequent measurement period from d 29-33), after which animals were changed to the other dietary treatment for a second 25-d period. Before both experimental periods, all animals received the CON diet for a 7 -d period (d 1-7).

\section{Diets, Feeding, and Housing}

Sainfoin cultivars 'Zeus' and 'Esparcette' were grown on a clay-type and sandy soil, respectively at the experimental facilities of the Plant Sciences Group (Unifarm) at Wageningen University. Both sainfoin cultivars were harvested at the end of the flowering period in the second vegetation cycle and separately ensiled in round bales. The characteristics of the silages are included in Table 1. The SAIN diet contained a mixture of both sainfoin silages in a ratio of 70:30 on DM basis for 'Zeus' and 'Esparcette', respectively (see Table 1). The CON diet was composed of grass silage $(600 \mathrm{~g} / \mathrm{kg}$ of DM), corn silage $(100 \mathrm{~g} / \mathrm{kg}$ of DM), concentrate $(240 \mathrm{~g} / \mathrm{kg}$ of DM), and linseed $(60 \mathrm{~g} / \mathrm{kg}$ of DM) prepared as a TMR. In the SAIN diet, half of the grass silage DM was replaced by the sainfoin silage mixture. The TMR were prepared twice a week, and daily portions per animal were weighed into bins and stored overnight at $4^{\circ} \mathrm{C}$ until feeding to limit nutrient losses through respiration (Wood and Parker, 1971). During each feed preparation, samples were taken from individual feedstuffs, which were pooled per week and stored at $-20^{\circ} \mathrm{C}$ pending chemical analyses. Diet formulation was identical for both experimental periods and the resulting chemical composition are summarized in Table 1. Diets were formulated to meet the energy and protein requirements of dairy cows (Van Es, 1975; Van Duinkerken et al., 2011).

Cows were fed individually and feed residues were collected to determine DMI throughout the experiment. The cows received their feed twice daily in equal portions at 0600 and $1600 \mathrm{~h}$. The cows were fed ad libitum during the 7 -d periods preceding the 25 -d experimental periods. From d 8 to 33 of each experimental period, diets were offered at $95 \%$ of ad libitum intake to minimize feed residues. When present, feed residues were collected once per day before the morning feeding and twice per day from d 29 to 33 of each period.

During the first $21 \mathrm{~d}$ (d 8-29) of each 25-d experimental period, cows were housed in tiestalls before being transported (100 m, $10 \mathrm{~min}$ ) in a trailer and housed individually in climate-controlled respiration chambers (CRC) for $4 \mathrm{~d}$ (d 29-33) to measure $\mathrm{CH}_{4}$ production, $\mathrm{O}_{2}$ consumption, and $\mathrm{CO}_{2}$ production, feed intake, feces and urine production to determine apparent total-tract digestibility, energy and $\mathrm{N}$ balance, and respiratory quotient (RQ). On d 8, 18, and 25 at $1500 \mathrm{~h}$, cows were housed for $48 \mathrm{~h}$ in the CRC for measurement of $\mathrm{CH}_{4}$ and rumen fluid sampling. The data of the latter 
Table 1. Feedstuff and chemical compositions (g/kg of DM unless otherwise noted) of TMR containing grass silage $(\mathrm{CON})$ or sainfoin silage (SAIN) used in the experiment ${ }^{1}$

\begin{tabular}{lrr}
\hline & \multicolumn{2}{c}{ Dietary treatment } \\
\cline { 2 - 3 } Item & CON & SAIN \\
\hline Ingredient $^{2}$ & & \\
Grass silage $^{3}$ & 600.0 & 300.0 \\
Sainfoin silage $^{3}$ & 0.0 & 300.0 \\
Corn silage $^{4}$ & 100.0 & 100.0 \\
Concentrate $^{5}$ & 240.0 & 240.0 \\
Linseed $^{6}$ & 60.0 & 60.0 \\
Chemical composition & & \\
DM, g/kg of product & 444.9 & 357.2 \\
OM & 918.9 & 891.3 \\
CP & 162.7 & 171.9 \\
NDF & 395.7 & 359.1 \\
ADF & 236.7 & 244.5 \\
ADL & 18.6 & 35.0 \\
Crude fat & 37.8 & 35.1 \\
Starch & 97.9 & 90.9 \\
Gross energy, MJ/kg of DM & 19.5 & 19.0 \\
Condensed tannins & 0.0 & 8.8 \\
\hline
\end{tabular}

${ }^{1}$ Values are means for 2 successive measurement periods. For all components, $\mathrm{NE}_{\mathrm{L}}$ was determined according to Van Es (1975).

${ }^{2}$ Grass silage: $\mathrm{DM}=366 \mathrm{~g} / \mathrm{kg}$ product; chemical composition $(\mathrm{g} / \mathrm{kg}$ of $\mathrm{DM}): \mathrm{OM}=907.1, \mathrm{CP}=145.9, \mathrm{NDF}=508.6, \mathrm{ADF}=306.3, \mathrm{ADL}=$ 14.3 , gross energy $(\mathrm{GE})=19.2 \mathrm{MJ} / \mathrm{kg}$ of $\mathrm{DM}, \mathrm{NE}_{\mathrm{L}}=7.4 \mathrm{MJ} / \mathrm{kg}$ of $\mathrm{DM} ; \mathrm{pH}=5.4$

${ }^{3}$ Sainfoin silage was a mixture of cultivar 'Zeus' silage from clay soil and cultivar 'Esparcette' from sandy soil (ratio between silages from 'Zeus' and 'Esparcette' $=70: 30$ on DM basis). Sainfoin 'Zeus' silage: $\mathrm{DM}=200 \mathrm{~g} / \mathrm{kg}$ product; chemical composition $(\mathrm{g} / \mathrm{kg}$ of $\mathrm{DM}): \mathrm{OM}$ $=785.2, \mathrm{CP}=212.3, \mathrm{NDF}=346.0, \mathrm{ADF}=305.3, \mathrm{ADL}=67.0, \mathrm{GE}$ $=17.1 \mathrm{MJ} / \mathrm{kg}$ of $\mathrm{DM}, \mathrm{NE}_{\mathrm{L}}=4.3 \mathrm{MJ} / \mathrm{kg}$ of $\mathrm{DM}$; condensed tannins $(\mathrm{CT})=24.0, \mathrm{pH}=5.5$. Sainfoin 'Esparcette' silage: $\mathrm{DM}=380 \mathrm{~g} / \mathrm{kg}$ of product; chemical composition $(\mathrm{g} / \mathrm{kg}$ of $\mathrm{DM})$ : $\mathrm{OM}=923.5, \mathrm{CP}=$ $96.5, \mathrm{NDF}=441.0, \mathrm{ADF}=336.5, \mathrm{ADL}=59.6, \mathrm{GE}=18.2 \mathrm{MJ} / \mathrm{kg}$ of $\mathrm{DM}, \mathrm{NE}_{\mathrm{L}}=5.3 \mathrm{MJ} / \mathrm{kg}$ of $\mathrm{DM} ; \mathrm{CT}=31.0, \mathrm{pH}=5.2$.

${ }^{4}$ Corn silage: $\mathrm{DM}=314 \mathrm{~g} / \mathrm{kg}$ of product, chemical composition $(\mathrm{g} / \mathrm{kg}$ $\mathrm{DM}): \mathrm{OM}=961.3, \mathrm{CP}=83.4, \mathrm{NDF}=354.9, \mathrm{ADF}=203.3, \mathrm{ADL}=$ 7.4, starch $=328.5, \mathrm{GE}=19.0 \mathrm{MJ} / \mathrm{kg}$ of $\mathrm{DM}, \mathrm{NE}_{\mathrm{L}}=6.9 \mathrm{MJ} / \mathrm{kg}$ of $\mathrm{DM} ; \mathrm{pH}=3.8$.

${ }^{5}$ Concentrate contained triticale $3.4 \%$, palm kernel flakes $11.8 \%$, stable rapeseed B $7.4 \%$, rapeseed meal $7.2 \%$, soybean meal $12.9 \%$, beet pulp $7.5 \%$, lime $1.53 \%$, magnesium oxide $0.1 \%$, mixing salt $0.42 \%$, molasses $5 \%$, sodium bicarbonate $0.25 \%$, corn gluten middling $8.9 \%$, corn 30.3\%, PRX AR 202 Melkvee B Basis 0.6\%, PRX AR 201 Melkvee A Prima (Agruniek-Rijnvallei, Wageningen, the Netherlands), $0.2 \%$ potato juice (protaminase). $\mathrm{DM}=893 \mathrm{~g} / \mathrm{kg}$ of product, chemical composition $(\mathrm{g} / \mathrm{kg}$ of $\mathrm{DM}): \mathrm{OM}=916.3, \mathrm{CP}=209.9, \mathrm{NDF}=221.2, \mathrm{ADF}$ $=122.5, \mathrm{ADL}=29.4$, crude fat $=40.3$, starch $=244.4, \mathrm{GE}=18.2$ $\mathrm{MJ} / \mathrm{kg}$ of $\mathrm{DM}, \mathrm{NE}_{\mathrm{L}}=7.4 \mathrm{MJ} / \mathrm{kg}$ of DM.

${ }^{6}$ Linseed: $\mathrm{DM}=922 \mathrm{~g} / \mathrm{kg}$ of product; chemical composition $(\mathrm{g} / \mathrm{kg}$ of $\mathrm{DM}): \mathrm{OM}=962.0, \mathrm{CP}=239.5, \mathrm{NDF}=201.3, \mathrm{ADF}=156.2, \mathrm{ADL}=$ 29.1 , crude fat $=417.9$, starch $=14.3, \mathrm{GE}=27.8 \mathrm{MJ} / \mathrm{kg}$ of $\mathrm{DM}, \mathrm{NE}_{\mathrm{L}}$ $=11.7 \mathrm{MJ} / \mathrm{kg}$ of DM.

measurements are provided elsewhere. The CRC were described in detail by Gerrits and Labussière (2015). Briefly, the volume of the individual chambers was 35 $\mathrm{m}^{3}$, and relative humidity was maintained at $70 \%$ at a temperature of $16^{\circ} \mathrm{C}$. Cows in the CRC were exposed to $16 \mathrm{~h}$ of light per day with the ventilation rate set at $42 \mathrm{~m}^{3} / \mathrm{h}$ per compartment, and the inlet and exhaust air of each compartment sampled at 10-min intervals. Gas concentrations and ventilation rates were corrected for pressure, temperature, and humidity to obtain standard temperature-pressure dew point volumes of inlet and exhaust air. Staff entered each CRC compartment twice daily at 0600 and $1600 \mathrm{~h}$ for approximately $30 \mathrm{~min}$ for milking and feeding. The gas measurements during these periods were excluded from data analysis. Water was freely available during the entire experiment.

\section{Measurements and Sampling}

Feed Intake and $\boldsymbol{B} \boldsymbol{W}$. Feed intake measurements determined from d 29 to 33 in each experimental period were used to calculate average nutrient intake per cow per day. Grass silage, corn silage, sainfoin silage, concentrate, and linseed were sampled and stored at $-20^{\circ} \mathrm{C}$ before being freeze-dried and ground in an cross beater mill (Peppink 100 AN, Deventer, the Netherlands) to pass through a 1-mm sieve. After grinding, all samples were stored at $4^{\circ} \mathrm{C}$ pending analysis. Feed ingredient samples were analyzed for DM, ash, N, NDF, ADF, ADL, crude fat, starch, gross energy $(\mathbf{G E})$, and CT.

In the CRC, feed residues were collected and weighed twice daily, before the morning and afternoon feedings, and stored at $4^{\circ} \mathrm{C}$. Residues were pooled per cow per period and then subsampled. Feed residue subsamples were oven-dried at $60^{\circ} \mathrm{C}$ and ground in a cross beater mill (Peppink $100 \mathrm{AN}$ ) to pass through a 1-mm sieve before DM analysis. Feed DMI was calculated by subtracting the dry weight of feed residues from the dry weight of feed offered. Body weight of cows was weighed and recorded immediately after entering and just before leaving the CRC.

Total Collection for Digestibility and Metabolizability. Apparent total-tract digestibility and metabolizability of nutrients were determined by quantitative separate collection of urine and feces (Figure 1). Cows were fitted with a handmade external urinary collection device constructed from a cone-shaped rubber funnel (0.5 mm; RX Superba, Eriks, Ede, the Netherlands), attached with Velcro to a rubber template $(1.5 \mathrm{~mm}$; RX Superba, Eriks) that fitted over the vulva and was glued to the shaved skin with medical glue (Hollister BV, Amersfoort, the Netherlands). The funnel was attached to a spiral polyvinyl chloride flexible tube (Delphinus S $32.0 \times 37.6 \mathrm{~mm}$, Mees van den Brink, Veenendaal, the Netherlands) attached to a sealed collection barrel. Urine was collected twice daily at 0600 and at $1600 \mathrm{~h}$ and weighed, and a $0.5 \%$ (wt/wt) urine subsample was collected each time and immediately stored at $-20^{\circ} \mathrm{C}$ to prevent $\mathrm{NH}_{3}$ losses. Urine subsamples were analyzed for total $\mathrm{N}$ and GE. Nitrogen retention $\left(\mathrm{g} / \mathrm{kg}\right.$ of $\mathrm{BW}^{0.75}$ per day) was estimated from $\mathrm{N}$ consumed through feed 


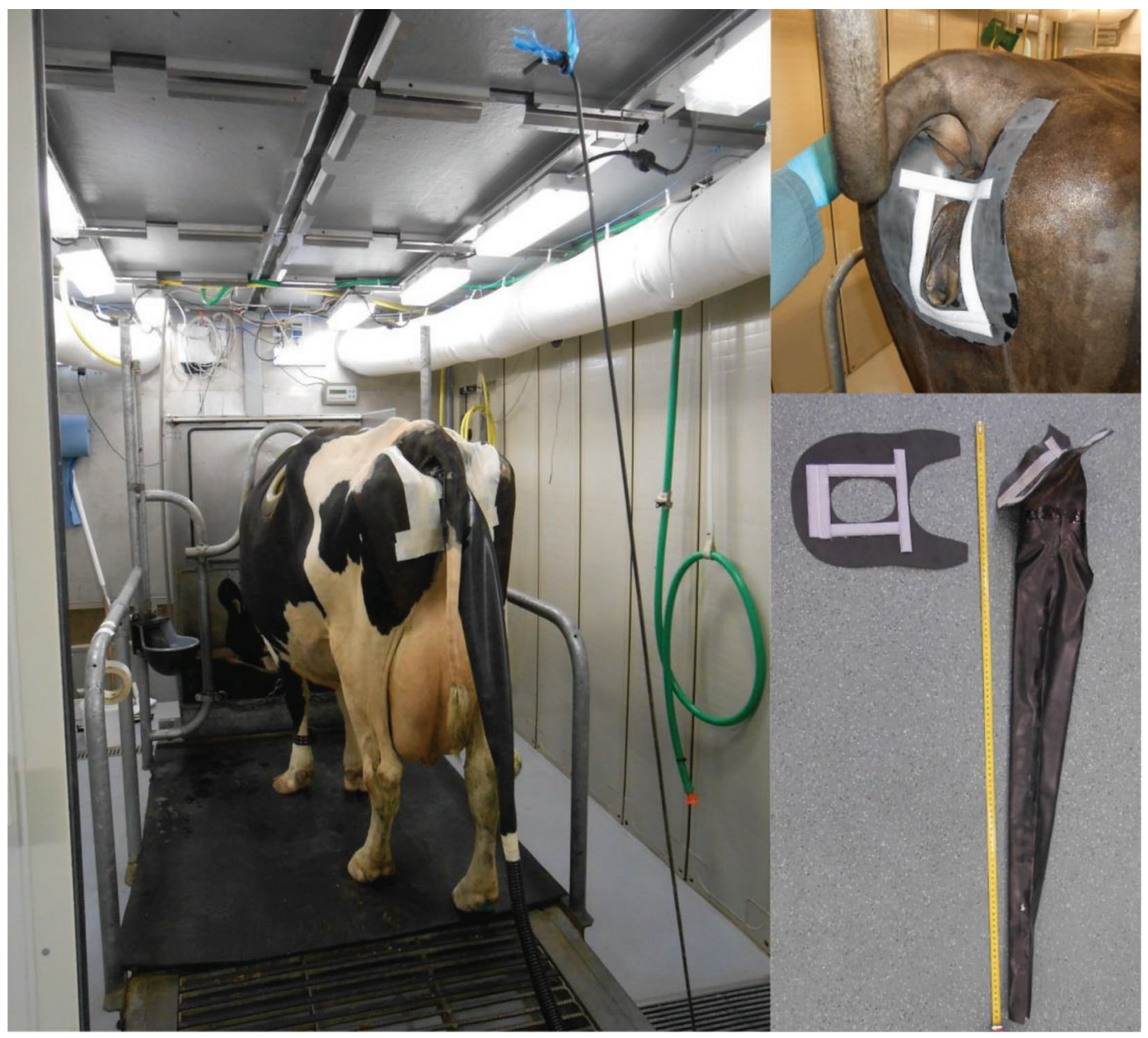

Figure 1. Cow in climate-controlled respiration chamber and (insets) urine collection device for quantitative urine collection. Color version available online.

(corrected for orts) and excreted in the feces, urine, and milk. Water that condensed from the chamber air on the heat exchanger was collected and analyzed for N. The ventilated chamber air was sampled continuously and flushed through a $25 \%$ solution of hydrosulfuric acid to trap ammonia. The amount of $\mathrm{N}$ trapped in acid was determined at the end of the experimental period and used to quantify $\mathrm{N}$ released via ventilated chamber air. Both $\mathrm{N}$ in condensed water and $\mathrm{N}$ trapped in acid were used to determine $\mathrm{N}$ retention. Feces were quantitatively collected from the CRC at the end of the 4-d measurement period and homogenized, and 3 subsamples of approximately $500 \mathrm{~g}$ each were collected in sealable containers and immediately stored in a freezer at $-20^{\circ} \mathrm{C}$. Two of the fecal subsamples were then freezedried, ground at $1 \mathrm{~mm}$, and stored at $4^{\circ} \mathrm{C}$ before analysis of DM, ash, N, NDF, ADF, crude fat, starch, and GE. The third fecal subsample was thawed overnight to ambient temperature and analyzed for DM and $\mathrm{N}$ in the wet material to determine $\mathrm{N}$ retention. Apparent digestibility of nutrients was calculated by the difference between intake and fecal output of the nutrient.

Milk was collected twice daily at 0600 and $1600 \mathrm{~h}$ from the cows in the CRC and recorded for individual cows. A milk sample $(10 \mathrm{~mL})$ of each milking was collected in a tube containing sodium azide $(5 \mu \mathrm{L})$ for preservation and analyzed for fat, protein, and lactose contents. Additional representative milk samples (5 g/ $\mathrm{kg}$ of milk) were taken at each milking, pooled per cow, and stored at $-20^{\circ} \mathrm{C}$ pending analyses for $\mathrm{N}$, urea, and energy in milk. Milk composition reported was corrected for differences in milk yield between individual milking events.

\section{Analytical Procedures}

Gross energy was determined using bomb calorimetry (IKA-C700, Janke \& Kunkel, Heitersheim, Germany; ISO 9831; ISO, 1998). Content of DM was determined gravimetrically after $4 \mathrm{~h}$ drying in a forced air stove at 
$103^{\circ} \mathrm{C}$ (ISO 6496 ; ISO, 1999b) with ash determined after incineration for $3 \mathrm{~h}$ in an oven at $550^{\circ} \mathrm{C}$ (ISO 5984; ISO, 2002). Nitrogen was determined using the Kjeldahl method with copper (II) sulfate as catalyst (ISO 5983-1; ISO, 2005). Crude fat was determined after hydrolysis with $\mathrm{HCl}$ and extraction with light petroleum at $60^{\circ} \mathrm{C}$ (ISO 6492; ISO, 1999a). Starch content was determined enzymatically according to method ISO 15914 (ISO, 2004a). Neutral detergent fiber was analyzed according to Van Soest et al. (1991) with the use of heat-stable amylase. The NDF contents reported include residual ash. Acid detergent fiber and ADL were determined according to Van Soest (1973). Milk fat, protein, and lactose were determined according to method ISO 9622 (ISO, 1999c) at VVB (Milk Control Station, Nunspeet, the Netherlands). Urea content in milk was analyzed based on the enzymatic $\mathrm{pH}$ difference method (ISO 14637; ISO, 2004b) and converted to MUN, based on urea containing $46.6 \% \mathrm{~N}$ on a molar basis.

Condensed tannins were analyzed by acetone-butanol$\mathrm{HCl}$ according to the method of Grabber et al. (2013), with slight modifications. In brief, approximately 10 mg of dried plant material was weighed into a screwcap test tube before $10 \mathrm{~mL}$ of acetone-butanol- $\mathrm{HCl}$ reagent was added. The latter reagent was prepared daily by first dissolving $150 \mathrm{mg}$ of ammonium ferric sulfate dodecahydrate in $3.3 \mathrm{~mL}$ of water and $5 \mathrm{~mL}$ of $12 M$ $\mathrm{HCl}$ before adding $42 \mathrm{~mL}$ of butanol-1-ol and $50 \mathrm{~mL}$ of acetone. The tubes were left at room temperature for $1 \mathrm{~h}$, after which they were heated at $70^{\circ} \mathrm{C}$ for 2.5 $\mathrm{h}$ in the dark, and air-cooled for $45 \mathrm{~min}$ to room temperature. The supernatants were transferred to quartz spectrophotometer cuvettes, the spectra were measured using a spectrophotometer (V530 Spectrophotometer, Jasco, Dunmow, UK) from 450 to $650 \mathrm{~nm}$, and the absorption of the anthocyanin peak was recorded. The $\mathrm{CT}$ concentration in the plant material was calculated using a standard with known tannin content to give an average response factor of 1 absorbance unit per 25 $\mu \mathrm{g}$ of purified CT. The tannins for this standard were extracted from sainfoin with $70 \%$ acetone:water, subjected to Sephadex LH-20 column (GE Healthcare Life Science, Piscataway, NJ) chromatography to obtain fraction 2, which contained $100 \mathrm{~g}$ of $\mathrm{CT} / 100 \mathrm{~g}$ of fraction (Williams et al., 2014). The CT concentration in plant material was expressed as a percentage of the total dry weight. Acetone-butanol-HCl reagent was used as a blank and as a diluent to keep maximal absorbance readings of anthocyanin peaks below 1.5 units.

\section{Energy and Nitrogen Balance Calculation}

Digestible (DEI) and metabolizable energy intake (MEI) per cow was calculated by subtracting the daily energy excreted in the feces (DEI) and urine and $\mathrm{CH}_{4}$ (MEI) from daily GE intake (GEI) through feed. Heat production (HP) was determined by indirect calorimetry at 10-min intervals (excluding the two 30min feeding periods) by measuring the exchange of $\mathrm{O}_{2}$, $\mathrm{CO}_{2}$, and $\mathrm{CH}_{4}$ according to the principles described by Gerrits and Labussière (2015). The RQ was calculated as the ratio between the volume of $\mathrm{CO}_{2}(\mathrm{~L})$ produced over the volume of $\mathrm{O}_{2}(\mathrm{~L})$ consumed (Brouwer, 1965). Energy retention (ER) in body mass was calculated by subtracting the daily HP and energy in milk from MEI. Energy retention as body protein $\left(\mathbf{E R}_{\mathbf{p}}\right)$ was derived from the protein gain $(\mathrm{N}$ retention $\times 6.25)$ multiplied by $23.6 \mathrm{~kJ} / \mathrm{g}$ (energetic value of body protein; Gerrits and Labussière, 2015). Energy retention as fat $\left(\mathbf{E R}_{\mathbf{f}}\right)$ was calculated from the difference between ER and $\mathrm{ER}_{\mathrm{p}}$. Energy retention data were expressed per kilogram of $\mathrm{BW}^{0.75}$ per day, where the mean $\mathrm{BW}$ per cow per balance period was used to calculate the metabolic BW.

\section{Statistical Analysis}

Effects of diet treatments on feed intake, nutrients digestibility, $\mathrm{CH}_{4}$ emissions, and $\mathrm{N}$ and energy utilization were tested by ANOVA using the MIXED procedure of SAS (SAS Institute, 2010) and the model

$$
\mathrm{Y}=\mu+\mathrm{A}_{i}+\mathrm{T}_{j}+\mathrm{P}_{k}+\varepsilon_{i j k},
$$

where $\mathrm{Y}=$ the dependent variable, $\mu=$ the overall mean, $\mathrm{A}_{i}=$ the effect of animal $(i=1$ to 6$), \mathrm{T}_{j}=$ the effect of diet treatments ( $j=1$ to 2 ), $\mathrm{P}_{k}=$ the effect of period ( $k=1$ to 2 ), and $\varepsilon_{i j k}=$ the residual error term. Treatment and period were independent variables and animal was a random variable. Data are presented as the least squares means and standard error of the means (LSM \pm SEM). Differences among main effects were analyzed using Tukey-Kramer's multiple comparison procedure in the LSMEANS statement of SAS (SAS Institute, 2010) with effects considered significant at $P \leq 0.05$ and a trend at $0.05<P \leq 0.10$. Order was initially included in the model but found to be not significant.

Respiratory quotient, $\mathrm{CH}_{4}$, and $\mathrm{HP}$ exchange rates for 60-min periods (expressed per $\mathrm{kg}$ of $\mathrm{BW}^{0.75}$ per day) were analyzed by repeated-measures ANOVA, using the MIXED procedure in SAS (2010) and applying a first-order antedependence covariance model (Wang and Goonewardene, 2004). Animal, diet, period, day, and hour were included as model main effects. Day was included in the REPEATED statement, with hour nested within day. Animal was included in the 
Table 2. Feed intake and digestibility of macronutrients of a TMR containing grass silage (CON) or sainfoin silage (SAIN) when fed to lactating dairy cows

\begin{tabular}{|c|c|c|c|c|c|}
\hline \multirow[b]{2}{*}{ Item } & \multicolumn{2}{|c|}{ Dietary treatment } & \multirow[b]{2}{*}{ SEM } & \multicolumn{2}{|c|}{$P$-value ${ }^{1}$} \\
\hline & $\mathrm{CON}$ & SAIN & & Treatment & Period \\
\hline \multicolumn{6}{|l|}{ Intake $(\mathrm{kg} / \mathrm{d})$} \\
\hline $\mathrm{DM}$ & 17.78 & 18.66 & 1.043 & 0.156 & 0.479 \\
\hline $\mathrm{OM}$ & 16.34 & 16.64 & 0.939 & 0.527 & 0.528 \\
\hline $\mathrm{N}$ & 0.47 & 0.52 & 0.028 & 0.027 & 0.333 \\
\hline $\mathrm{NDF}$ & 7.04 & 6.70 & 0.383 & 0.091 & 0.126 \\
\hline $\mathrm{ADF}$ & 4.21 & 4.56 & 0.252 & 0.051 & 0.138 \\
\hline Crude fat & 0.68 & 0.67 & 0.038 & 0.354 & 0.480 \\
\hline Starch & 1.78 & 1.74 & 0.099 & 0.391 & 0.211 \\
\hline \multicolumn{6}{|c|}{ Digestibility (g/kg) } \\
\hline $\mathrm{DM}$ & 727.9 & 688.2 & 4.01 & 0.0001 & 0.447 \\
\hline $\mathrm{OM}$ & 746.7 & 717.7 & 3.37 & 0.003 & 0.275 \\
\hline $\mathrm{N}$ & 661.6 & 650.7 & 13.11 & 0.573 & 0.282 \\
\hline $\mathrm{NDF}$ & 667.8 & 577.3 & 6.50 & 0.0004 & 0.147 \\
\hline $\mathrm{ADF}$ & 658.2 & 573.5 & 12.81 & 0.009 & 0.218 \\
\hline Crude fat & 508.4 & 524.9 & 37.65 & 0.655 & 0.283 \\
\hline Starch & 938.9 & 910.6 & 9.74 & 0.105 & 0.298 \\
\hline \multicolumn{6}{|c|}{ Nutrient digested $(\mathrm{kg} / \mathrm{d})$} \\
\hline DM digested & 12.95 & 12.83 & 0.739 & 0.671 & 0.204 \\
\hline OM digested & 12.20 & 11.94 & 0.685 & 0.375 & 0.636 \\
\hline $\mathrm{N}$ digested & 0.31 & 0.34 & 0.022 & 0.097 & 0.232 \\
\hline
\end{tabular}

${ }^{1}$ Differences between treatment and period were considered significant at $P \leq 0.05$.

SUBJECT statement, with animal nested within diet $\times$ period, thus correlating the diurnal measurements on the same animal and diet. Differences among main effects were analyzed using Tukey-Kramer's multiple comparison procedure in the LSMEANS statement in SAS, with effects considered significant at $P \leq 0.05$ and a trend at $0.05<P \leq 0.10$.

\section{RESULTS}

\section{Feed Intake and Animal Performance}

Results on feed intake and nutrient digestibility are shown in Table 2. No differences between treatment on DM, OM, NDF, crude fat, or starch intake of the cows were observed. However, $\mathrm{N}$ intake was greater $(P$ $=0.027$ ) for the SAIN diet with a trend observed for $\operatorname{NDF}(P=0.091)$ and $\operatorname{ADF}(P=0.051)$. Apparent digestibility of DM, OM, NDF, and ADF were lower $(P \leq 0.009)$ for the SAIN diet. The absolute amounts of DM and OM digested per day did not differ between treatments, but the amount of $\mathrm{N}$ digested tended $(P=$ 0.097) to be greater for the SAIN diet compared with the CON diet. Total milk yield and milk per kilogram of OM digested was greater $(P \leq 0.042)$ for the SAIN diet (Table 3). Fat- and protein-corrected milk production (FPCM) and total daily milk protein yield tended to be greater $(P \leq 0.082)$ for the SAIN diet. We detected no differences $(P=0.209)$ between treatments on milk fat content, whereas milk protein content tended $(P=$
$0.065)$ to be greater and MUN tended $(P=0.070)$ to be lower for the CON diet.

\section{Methane Production}

Methane production expressed in grams per day was not different between the 2 diets (Table 4). However, because of a numerically greater DMI for the SAIN diet, $\mathrm{CH}_{4}$ expressed per kilogram of DMI was lower $(P$ $=0.005)$ for the SAIN diet. Methane expressed relative to GEI tended $(P=0.063)$ to be lower for the SAIN diet. However, $\mathrm{CH}_{4}$ expressed per kilogram of milk and per kilogram of FPCM were not different between the 2 diets.

\section{Energy and Nitrogen Balance}

We found no differences between treatments on GEI, $\mathrm{CH}_{4}$, energy in milk, energy in urine, or HP (Table 5). Energy in feces was greater $(P=0.039)$ for the SAIN diet compared with the CON diet. As a result, total energy retention of the cows was highest $(P=0.025)$ for the CON diet. Total energy retention expressed relative to GEI (ER\% of GEI) was lower $(P=0.050)$ for the SAIN diet; $\mathrm{ER}_{\mathrm{p}}$ was greater $(P=0.038)$, whereas $\mathrm{ER}_{\mathrm{f}}$ was lower $(P=0.007)$ for cows fed the SAIN diet.

Cows had greater $(P=0.022) \mathrm{N}$ intake when fed the SAIN diet than fed the CON diet (Table 5). We detected no differences in $\mathrm{N}$ excreted in milk and urine between the 2 diets. The $\mathrm{N}$ retention and $\mathrm{N}$ excreted in 
Table 3. Milk yield and milk composition in dairy cows fed a TMR containing grass silage (CON) and sainfoin silage (SAIN)

\begin{tabular}{|c|c|c|c|c|c|}
\hline \multirow[b]{2}{*}{ Item } & \multicolumn{2}{|c|}{ Dietary treatment } & \multirow[b]{2}{*}{ SEM } & \multicolumn{2}{|c|}{$P$-value ${ }^{2}$} \\
\hline & $\mathrm{CON}$ & SAIN & & Treatment & Period \\
\hline \multicolumn{6}{|l|}{ Milk yield } \\
\hline Milk $(\mathrm{kg} / \mathrm{d})$ & 22.01 & 24.08 & 2.457 & 0.042 & 0.263 \\
\hline Milk (kg/kg of OM digested) & 1.78 & 1.99 & 0.115 & 0.033 & 0.207 \\
\hline $\operatorname{FPCM}^{1}(\mathrm{~kg} / \mathrm{d})$ & 24.13 & 25.69 & 2.464 & 0.080 & 0.189 \\
\hline FPCM ( $\mathrm{kg} / \mathrm{kg}$ of OM digested) & 1.95 & 2.13 & 0.109 & 0.103 & 0.227 \\
\hline Fat $(\mathrm{g} / \mathrm{d})$ & $1,050.3$ & $1,102.9$ & 112.09 & 0.191 & 0.199 \\
\hline Protein $(\mathrm{g} / \mathrm{d})$ & 755.4 & 796.6 & 65.09 & 0.082 & 0.224 \\
\hline \multicolumn{6}{|l|}{ Milk composition } \\
\hline Fat $(\%)$ & 4.85 & 4.70 & 0.175 & 0.209 & 0.688 \\
\hline Protein (\%) & 3.54 & 3.38 & 0.200 & 0.065 & 0.405 \\
\hline Lactose $(\%)$ & 4.45 & 4.49 & 0.094 & 0.345 & 0.671 \\
\hline MUN (mg/dL) & 11.61 & 11.89 & 0.317 & 0.070 & 0.432 \\
\hline
\end{tabular}

${ }^{1} \mathrm{FPCM}=$ fat- and protein-corrected milk $=(0.337+0.116 \times \%$ fat $+0.06 \times \%$ protein $) \times$ milk production $(\mathrm{kg} / \mathrm{d})$; van Gastelen et al. (2015).

${ }^{2}$ Differences between treatment and period were considered significant at $P \leq 0.05$.

feces were greater $(P \leq 0.038)$ for cows fed the SAIN diet.

\section{Diurnal Patterns of $H P, R Q$, and $\mathrm{CH}_{4}$}

Diurnal patterns of $\mathrm{HP}, \mathrm{RQ}$, and $\mathrm{CH}_{4}$ are shown in Figure 2. During the day, HP patterns did not differ $(P$ $\geq 0.345$ ) between the 2 diets at any time point. The $\mathrm{CH}_{4}$ production pattern for SAIN-fed cows was numerically lower between 2200 and $0600 \mathrm{~h}$ compared with CON-fed cows, with a significant $(P=0.002)$ effect observed at $2400 \mathrm{~h}$. However, after the afternoon feeding, the $\mathrm{CH}_{4}$ production for SAIN-fed cows was numerically $(P=0.717)$ greater at $1800 \mathrm{~h}$. The RQ pattern of the cows was greater $(P<0.0001)$ during the early morning at $0500 \mathrm{~h}$ and numerically greater $(P \geq 0.715)$ after the morning feeding (0700 to $1000 \mathrm{~h}$ ), in the afternoon (1500 to $1700 \mathrm{~h}$ ), and in the late evening (2100 to 2400 h) when fed the CON diet. As a result, the average of RQ tended $(P=0.066)$ to be greater for the CON diet than for the SAIN diet.

\section{DISCUSSION}

\section{Feed Intake and Nutrient Digestibility}

We detected no significant differences in feed DMI of the cows when fed the 2 diets. However, due to compositional differences, $\mathrm{ADF}$ and $\mathrm{N}$ intake were greater for the SAIN diet. The average CT content in the 2 cultivars of sainfoin silage was $26.3 \mathrm{~g} / \mathrm{kg}$ of DM, which resulted in a CT content in the SAIN diet of $8.8 \mathrm{~g}$ of CT/ $\mathrm{kg}$ of DM. Substituting grass silage for sainfoin silage in the TMR of the cows fed at $95 \%$ of ad libitum did not reduce DMI in the present study. The palatability of the sainfoin silage was, therefore, at least comparable to that of the grass silage, and the intake of $8.8 \mathrm{~g}$ of $\mathrm{CT} / \mathrm{kg}$ of DM did not affect DMI. Beauchemin et al. (2007) reported that DMI was not different in growing beef cattle fed a forage-based diet supplemented with quebracho tannin extract at levels of 0,9 , and $18 \mathrm{~g}$ of $\mathrm{CT} / \mathrm{kg}$ of DM diet. Waghorn et al. (1994) reported that consumption of Lotus pedunculatus with high CT

Table 4. Methane $\left(\mathrm{CH}_{4}\right)$ emissions from dairy cows fed a TMR containing grass silage (CON) and sainfoin silage (SAIN)

\begin{tabular}{|c|c|c|c|c|c|}
\hline \multirow[b]{2}{*}{ Item $^{1}$} & \multicolumn{2}{|c|}{ Dietary treatment } & \multirow[b]{2}{*}{ SEM } & \multicolumn{2}{|c|}{$P$-value ${ }^{2}$} \\
\hline & $\mathrm{CON}$ & SAIN & & Treatment & Period \\
\hline $\mathrm{CH}_{4}(\mathrm{~g} / \mathrm{d})$ & 365.5 & 360.8 & 19.76 & 0.677 & 0.514 \\
\hline $\mathrm{CH}_{4}(\mathrm{~g} / \mathrm{kg}$ of $\mathrm{DMI})$ & 20.58 & 19.38 & 0.349 & 0.005 & 0.739 \\
\hline $\mathrm{CH}_{4}(\mathrm{~g} / \mathrm{kg}$ of $\mathrm{DM}$ digested $)$ & 28.27 & 28.15 & 0.453 & 0.809 & 0.547 \\
\hline $\mathrm{CH}_{4}(\mathrm{~g} / \mathrm{kg}$ of $\mathrm{OM}$ digested $)$ & 29.99 & 30.28 & 0.439 & 0.498 & 0.619 \\
\hline $\mathrm{CH}_{4}(\mathrm{~g} / \mathrm{kg}$ of milk $)$ & 17.64 & 15.49 & 1.466 & 0.157 & 0.275 \\
\hline $\mathrm{CH}_{4}(\mathrm{~g} / \mathrm{kg}$ of $\mathrm{FPCM})$ & 15.81 & 14.36 & 0.993 & 0.221 & 0.262 \\
\hline $\mathrm{CH}_{4}(\%$ of $\mathrm{GEI})$ & 5.86 & 5.71 & 1.000 & 0.063 & 0.135 \\
\hline
\end{tabular}

${ }^{1} \mathrm{FPCM}=$ fat- and protein-corrected milk $=(0.337+0.116 \times \%$ fat $+0.06 \times \%$ protein $) \times$ milk production $(\mathrm{kg} / \mathrm{d})$; van Gastelen et al. (2015); GEI = gross energy intake.

${ }^{2}$ Differences between treatment and period were considered significant at $P \leq 0.05$. 
men, by shielding the polysaccharides from microbial enzymatic hydrolysis. Although apparent digestibility of DM and OM was lower for the SAIN diet, the absolute amount of DM and OM digested did not differ between diet treatments. This could be explained by the numerical increase in DMI and OMI for the SAIN diet compared with the CON diet.
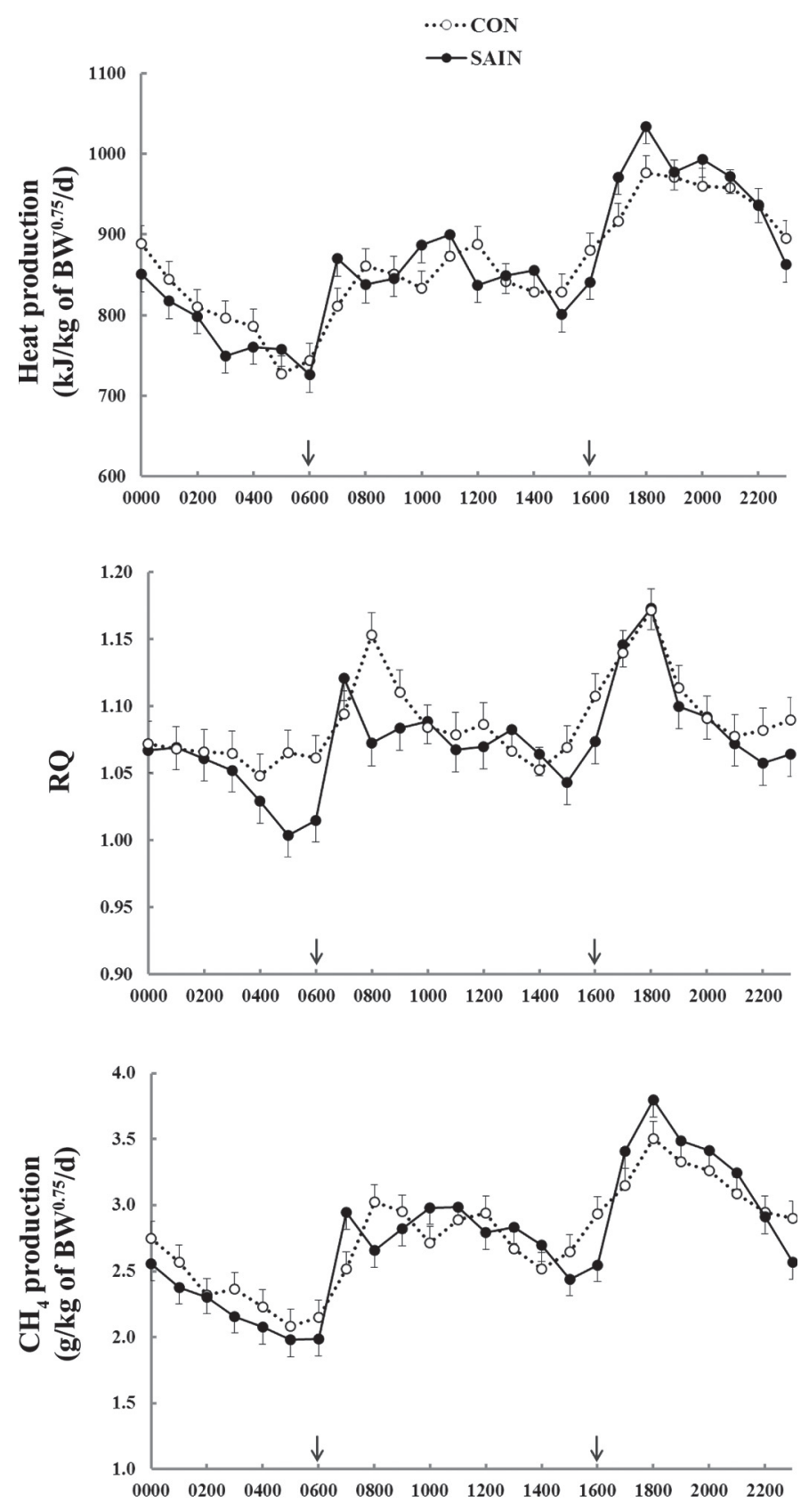

Time of day (h)

Figure 2. Diurnal pattern of heat production, respiratory quotient (RQ), and $\mathrm{CH}_{4}$ production of dairy cows fed a TMR containing grass silage $(\mathrm{CON} ; \bigcirc)$ or sainfoin silage $(\mathrm{SAIN} ; \bullet)$. Arrows $=$ feeding time.

\section{Milk Production}

Milk yield of lactating ewes increased by $21 \%$ during mid to late lactation when the ewes were fed Lotus corniculatus containing $44.5 \mathrm{~g}$ of total $\mathrm{CT} / \mathrm{kg}$ of $\mathrm{DM}$ diet, compared with ewes fed L. corniculatus in combination with polyethylene glycol (molecular weight of 3,500; Wang et al., 1996a), whereas the authors showed that the OM intake $(2 \mathrm{~kg} / \mathrm{d})$ was similar between the 2 diets. A similar experiment with dairy cows was conducted by Woodward et al. (2000), who found that milk yields were greater on L. corniculatus $(21.2 \mathrm{~kg} /$ cow per d) than on ryegrass $(15.5 \mathrm{~kg} / \mathrm{cow}$ per day), whereas there was no effect of intake. Similarly, in the current study, milk yield was $2 \mathrm{~kg} / \mathrm{cow}$ per day greater for the SAIN diet even though feed intake and nutrients digested in absolute terms were similar between the 2 diets. A possible explanation could be that energy retention as body protein $\left(\mathrm{ER}_{\mathrm{p}}\right)$ of the cows when fed the SAIN diet was greater whereas energy retention as body fat $\left(\mathrm{ER}_{\mathrm{f}}\right)$ was lower when fed the SAIN diet (Table 5). This means that energy efficiency for production in cows fed the SAIN diet was greater than that in cows on the CON diet. During the measurement period in the CRC, all cows showed a minor loss of BW $(-3.2 \pm 0.69 \mathrm{~kg}$; mean \pm SEM) with no difference between the SAIN (average $-3.0 \mathrm{~kg}$ ) and CON (average $-3.5 \mathrm{~kg}$ ) diets. This would suggest that cows receiving the SAIN diet redirected more energy into milk rather than into the body tissue, especially in mid to late lactation, when cows are starting to deposit energy in the body, and this could be beneficial. Another aspect of the increase in milk production could be related to the sainfoin containing $\mathrm{CT}$, which reduced protein degradation in the rumen, resulting in an increase in EAA available for absorption in the small intestine, as shown in previous studies (Waghorn et al., 1987; Scharenberg et al., 2007). Leucine, valine, arginine, and ornithine are the most limiting AA for milk production (Derrig et al., 1974). Therefore, increasing milk yield in our study could be due to increasing absorption of EAA in the small intestine. In future studies, it would be interesting to measure the effect of sainfoin on EAA supply in the small intestine.

\section{Methane Production}

The reduction in $\mathrm{CH}_{4}$ emissions observed in the current study could be explained by a decrease in fiber digestibility in the rumen, which agrees with the lower $\mathrm{CH}_{4}$ production. The products of fiber fermentation are acetate and butyrate, the biochemical pathways that liberate $2[\mathrm{H}]^{-}$ions, and which are used in the rumen to produce $\mathrm{CH}_{4}$, whereas propionate production is consid- 
ered as an $\mathrm{H}_{2}$ sink (Tavendale et al., 2005). In addition, the SAIN diet contained CT, which have been shown to reduce ruminal methanogenesis and decrease ruminal protozoa numbers in some studies (Tavendale et al., 2005; Bhatta et al., 2009). In the current study, the $\mathrm{CH}_{4}$ emission per kilogram of FPCM was 15.81 and $14.36 \mathrm{~g}$ for the cows fed the CON and SAIN diets, respectively. These results are in line with those reported by van Gastelen et al. (2015) and Warner et al. (2015), who found that the $\mathrm{CH}_{4}$ emissions per kilogram of FPCM ranged from 14.6 to $17.4 \mathrm{~g}$.

In our experiment, total daily $\mathrm{CH}_{4}$ emissions were similar between the 2 diets. However, cows fed the SAIN diet produced less $\mathrm{CH}_{4}$ per kilogram of DMI. These observations are in line with Woodward et al. (2002), who compared the $\mathrm{CH}_{4}$ emission and milk yield in dairy cows fed either Hedysarum coronarium (CT-containing forage) or perennial ryegrass and found that $\mathrm{CH}_{4}$ emission per kilogram of DMI was lower in the cows fed $H$. coronarium. These results suggest that sainfoin could be an interesting roughage to be used in dairy cow diets as it resulted in $\mathrm{CH}_{4}$ emissions in the lower range compared with cows receiving grass silage or maize silage-based diets.

\section{Energy Balance}

The observed MEI:GEI ratio for the CON diet is in line with those reported by van Gastelen et al. (2015) and Warner et al. (2015), indicating that the animals received a diet of good quality. The SAIN fed cows had a 3.7-percentage-unit lower MEI:GEI ratio compared with CON, suggesting a slightly lower diet quality. The difference in MEI:GEI ratio between the 2 diets could be mainly ascribed to the decreased apparent energy digestibility (DEI:GEI, $73.0 \%$ for CON vs. $69.0 \%$ for SAIN) in the SAIN diet and to a somewhat lower metabolizability of the DEI (MEI:DEI, $87.0 \%$ for CON vs. $86.0 \%$ for SAIN). The energy retained (ER) in body mass was significantly greater in animals on the CON diet compared with the SAIN diet and considerably greater compared with studies of van Gastelen et al. (2015) and Warner et al. (2015). Those studies used dairy cows in mid lactation, whereas the animals in the current study were already in late lactation at the start of the experiment. Chilliard et al. (1991) demonstrated that cows nearing the end of lactation start accreting more body fat relative to body protein. The CON diet animals showed that about $92 \%$ of the ER was related to $\mathrm{ER}_{\mathrm{f}}$ and $8 \%$ to $\mathrm{ER}_{\mathrm{p}}$. In contrast, the SAIN diet showed that only $63.0 \%$ of ER was deposited as $\mathrm{ER}_{\mathrm{f}}$ and $37.0 \%$ to $\mathrm{ER}_{\mathrm{p}}$, suggesting that metabolism in animals receiving the SAIN diet was redirected. A possible explanation could be that the CT in the SAIN diet modified the microbial profile or composition and microbial activity, resulting in more propionate than acetate. Acetate is an important precursor for fat metabolism (Livesey and Elia, 1988). Jones et al. (1994) found that CT inhibited the growth of Butyrivibrio fibrisolvens, which are involved in fiber fermentation. The RQ tended to be greater for cows on the CON diet compared with cows on SAIN, which also indicates that nutrient metabolism could have differed between the 2 diets. The greater RQ for the CON-fed cows could be because the energy retained as body fat in these animals was greater than that of the SAIN-fed animals. In ruminants, lipogenesis mainly occurs in adipose tissue, for which acetate and butyrate are important precursors. Reducing equivalents (NADPH) needed for fatty acid synthesis come from glucose through the pentose phosphate cycle, a process that produces $\mathrm{CO}_{2}$ (Livesey and Elia, 1988). This means that the more fatty acids are synthesized, the more $\mathrm{CO}_{2}$ is produced, and, as a result, a greater RQ is obtained.

\section{Nitrogen Balance}

Nitrogen intake and $\mathrm{N}$ retention were greater on the SAIN diet, which could be related to the CP (171.9 g/ $\mathrm{kg}$ of DM) in the SAIN diet, which was numerically greater than that of the CON diet $(162.6 \mathrm{~g} / \mathrm{kg}$ of DM). Improvement of $\mathrm{N}$ retention in cows fed the SAIN diet could be explained by content of $\mathrm{CT}$, which reduces degradation of protein in the rumen and improves microbial protein synthesis (Getachew et al., 2000, 2008). This would increase the total supply of nonammonia $\mathrm{N}$ to the duodenum and absorption from the intestine (Waghorn et al., 1987). The reduction of protein degradation in the rumen may occur due to the formation of tannin-protein complexes in the rumen $\mathrm{pH}$ and inhibition of the growth and activity of proteolytic bacterial populations (Mueller-Harvey, 2006).

Fecal $\mathrm{N}$ excretion also was greater for the SAIN diet, whereas we observed no difference in urinary $\mathrm{N}$ excretion between the 2 diets. These observations are in line with the study of Scharenberg et al. (2007), who found that urinary $\mathrm{N}$ excretion was lower and feces $\mathrm{N}$ excretion was greater for lambs fed sainfoin silage compared with those fed grass-clover silage. Greater fecal $\mathrm{N}$ excretion has been reported in a study with CT-containing diets (Grainger et al., 2009), where CT-protein complexes may not have been completely dissociated in the abomasum and lower digestive tract. Shifting the excretion pattern of $\mathrm{N}$ from urine to feces is beneficial to the environment because feces $\mathrm{N}$ is mainly in the organic form, which is less volatile compared with ammonia, whereas urinary $\mathrm{N}$ is more rapidly hydrolyzed to ammonia and nitrified to nitrate (Dijkstra et al., 2011). 
Nitrate can leach into groundwater, causing water pollution and it can be converted to nitrous oxide, which contributes to global warming (Eckard et al., 2010).

\section{CONCLUSIONS}

The inclusion of sainfoin silage in the diet of lactating dairy cows reduced nutrient digestibility and $\mathrm{CH}_{4}$ production per kilogram of DMI, while increasing milk production and improving $\mathrm{N}$ utilization. Moreover, inclusion of sainfoin silage in the diet resulted in greater efficiency with which ME intake was transformed into milk and energy retained in body protein. This suggests that sainfoin silage, or CT in sainfoin silage, affects metabolism and redirects it toward body protein accretion instead of body fat in late-lactation cows, resulting in leaner animals. Sainfoin silage has potential to be used in TMR for dairy cows to increase milk production.

\section{ACKNOWLEDGMENTS}

The authors thank Bert Beukers, Willem van Ommeren, Teus Bleijenberg, and Ries Verkerk of the animal research facilities Carus of Wageningen University for their assistance with the dairy cow experiment; Stijn van de Goor for the technical assistance as part of his undergraduate course at Wageningen University, Wageningen, the Netherlands; Garry Waghorn (Dairy NZ, Hamilton New Zealand) for sharing his ideas on the urine collection device and views on tannin-related research; and Walter Gerrits (Animal Nutrition Group, Wageningen University, Wageningen, the Netherlands) for advice on the CRC data analyses. Irene MuellerHarvey and Chris Drake (Reading University, Reading, UK) are acknowledged for the tannin analyses. This research was financially supported by European Union grant "LegumePlus" (PITN-GA-2011-289377). The authors report no conflicts of interest.

\section{REFERENCES}

Al-Dobaib, S. N. 2009. Effect of different levels of quebracho tannin on nitrogen utilization and growth performance of Najdi sheep fed alfalfa (Medicago sativa) hay as a sole diet. Anim. Sci. J. 80:532-541.

Alexander, G., B. Singh, A. Sahoo, and T. K. Bhat. 2008. In vitro screening of plant extracts to enhance the efficiency of utilization of energy and nitrogen in ruminant diets. Anim. Feed Sci. Technol. 145:229-244.

Bae, H. D., T. A. McAllister, J. Yanke, K.-J. Cheng, and A. D. Muir 1993. Effects of condensed tannins on endoglucanase activity and filter paper digestion by Fibrobacter succinogenes S85. Appl. Environ. Microbiol. 59:2132-2138.

Barry, T. N., and T. R. Manley. 1986. Interrelationships between the concentrations of total condensed tannin, free condensed tannin and lignin in Lotus sp. and their possible consequences in ruminant nutrition. J. Sci. Food Agric. 37:248-254.
Beauchemin, K. A., S. M. McGinn, T. F. Martinez, and T. A. McAllister. 2007. Use of condensed tannin extract from quebracho trees to reduce methane emissions from cattle. J. Anim. Sci. 85:1990-1996.

Bhatta, R., Y. Uyeno, K. Tajima, A. Takenaka, Y. Yabumoto, I. Nonaka, O. Enishi, and M. Kurihara. 2009. Difference in the nature of tannins on in vitro ruminal methane and volatile fatty acid production and on methanogenic archaea and protozoal populations. J. Dairy Sci. 92:5512-5522.

Brouwer, E. 1965. Report of the sub-committee on constants and factors. Pages 441-443 in Proc. 3rd Symp. Energy Metabolism, Troon, Scotland. K. L. Blaxter, ed. EAAP Publication no 11. Academic Press, London, UK.

Carulla, J. E., M. Kreuzer, A. Machmüller, and H. D. Hess. 2005. Supplementation of Acacia mearnsii tannins decreases methanogenesis and urinary nitrogen in forage-fed sheep. Aust. J. Agric. Res. 56:961-970.

Castillejos, L., S. Calsamiglia, J. Martín-Tereso, and H. Ter Wijlen. 2008. In vitro evaluation of effects of ten essential oils at three doses on ruminal fermentation of high concentrate feedlot-type diets. Anim. Feed Sci. Technol. 145:259-270.

Chilliard, Y., M. Cissé, R. LeFaivre, and B. Rémond. 1991. Body composition of dairy cows according to lactation stage, somatotropin treatment, and concentrate supplementation. J. Dairy Sci. 74:3103-3116.

Copani, G., C. Ginane, A. Quereuil, F. Anglard, and V. Niderkorn. 2015. Benefit of including bioactive legumes (sainfoin, red clover) in grass-based silages on ruminant production and pollutant emissions. PhD Thesis. Université Blaise Pascal, Vet Agro Sup, UMR Herbivores, Clermont-Ferrand, France.

Derrig, R. G., J. H. Clark, and C. L. Davis. 1974. Effect of abomasal infusion of sodium caseinate on milk yield, nitrogen utilization and amino acid nutrition of the dairy cow. J. Nutr. 104:151-159.

Dijkstra, J., O. Oenema, and A. Bannink. 2011. Dietary strategies to reducing $\mathrm{N}$ excretion from cattle: Implications for methane emissions. Curr. Opin. Environ. Sustain. 3:414-422.

Eckard, R. J., C. Grainger, and C. A. M. de Klein. 2010. Options for the abatement of methane and nitrous oxide from ruminant production: A review. Livest. Sci. 130:47-56.

Gerber, P. J., H. Steinfeld, B. Henderson, A. Mottet, C. Opio, J. Dijkman, A. Falcucci, and G. Tempio. 2013. Tackling climate change through livestock: A global assessment of emissions and mitigation opportunities. Food and Agriculture Organization of the United Nations (FAO), Rome, Italy.

Gerrits, W. J. J., and E. Labussière. 2015. Computing energy expenditure from indirect calorimetry data: A calculation exercise (Chapter 14). Pages 275-283 in Indirect Calorimetry: Techniques, Computations, and Applications. Wageningen Academic Publishers, Wageningen, the Netherlands. http:// dx.doi.org/10.3920/978-90-8686-809-4.

Getachew, G., H. P. S. Makkar, and K. Becker. 2000. Effect of polyethylene glycol on in vitro degradability ofnitrogen and microbial protein synthesis from tannin-rich browse and herbaceous legumes. Br. J. Nutr. 84:73-83.

Getachew, G., W. Pittroff, D. H. Putnam, A. Dandekar, S. Goyal, and E. J. DePeters. 2008. The influence of addition of gallic acid, tannic acid, or quebracho tannins to alfalfa hay on in vitro rumen fermentation and microbial protein synthesis. Anim. Feed Sci. Technol. 140:444-461.

Grabber, J. H., W. E. Zeller, and I. Mueller-Harvey. 2013. Acetone enhances the direct analysis of procyanidin-and prodelphinidin-based condensed tannins in Lotus species by the butanol-HCl-iron assay. J. Agric. Food Chem. 61:2669-2678.

Grainger, C., T. Clarke, M. J. Auldist, K. A. Beauchemin, S. M. McGinn, G. C. Waghorn, and R. J. Eckard. 2009. Potential use of Acacia mearnsii condensed tannins to reduce methane emissions and nitrogen excretion from grazing dairy cows. Can. J. Anim. Sci. 89:241-251.

Hatew, B., C. Hayot Carbonero, E. Stringano, L. F. Sales, L. M. J. Smith, I. Mueller-Harvey, W. H. Hendriks, and W. F. Pellikaan. 2015a. Diversity of condensed tannin structures affects rumen in 
vitro methane production in sainfoin (Onobrychis viciifolia) accessions. Grass Forage Sci. 70:474-490.

Hatew, B., E. Stringano, I. Mueller-Harvey, W. H. Hendriks, C. Hayot Carbonero, L. M. J. Smith, and W. F. Pellikaan. 2015b. Impact of variation in structure of condensed tannins from sainfoin (Onobrychis viciifolia) on in vitro ruminal methane production and fermentation characteristics. J. Anim. Physiol. Nutr. http://dx.doi. org/10.1111/jpn.12336.

Hayot Carbonero, C., I. Mueller-Harvey, T. A. Brown, and L. M. J. Smith. 2011. Sainfoin (Onobrychis viciifolia): A beneficial forage legume. Plant. Genet. Res. 9:70-85.

Hoste, H., J. F. J. Torres-Acosta, C. A. Sandoval-Castro, I. Mueller-Harvey, S. Sotiraki, H. Louvandini, S. M. Thamsborg, and T. H. Terrill. 2015. Tannin containing legumes as model for nutraceuticals against digestive parasites in livestock. Vet. Parasitol. 212:5-17.

ISO. 1998. Animal feeding stuffs, animal products, and faeces or urineDetermination of gross calorific value-Bomb calorimeter method. ISO 9831:1998. International Organization for Standardization (ISO), Geneva, Switzerland.

ISO. 1999a. Animal feeding stuffs-Determination of fat content. ISO 6492:1999. International Organization for Standardization (ISO), Geneva, Switzerland.

ISO. 1999b. Animal feeding stuffs-Determination of moisture and other volatile matter content. ISO 6496:1999. International Organization for Standardization (ISO), Geneva, Switzerland.

ISO. 1999c. Whole milk-Determination of milk fat, protein and lactose content-Guidance on the operation of mid-infrared instruments. ISO 9622:1999. International Organization for Standardization (ISO), Geneva, Switzerland.

ISO. 2002. Animal feeding stuffs-Determination of crude ash. ISO 5984:2002. International Organization for Standardization (ISO), Geneva, Switzerland.

ISO. 2004a. Animal feeding stuffs-Enzymatic determination of total starch content. ISO 15914:2004. International Organization for Standardization (ISO), Geneva, Switzerland.

ISO. 2004b. Milk-Determination of urea content-Enzymatic method using difference in $\mathrm{pH}$. ISO 14637:2004. International Organization for Standardization (ISO), Geneva, Switzerland.

ISO. 2005. Animal feeding stuffs-Determination of nitrogen content and calculation of crude protein content-Part 1. Kjeldahl method. ISO 5983-1:2005. International Organization for Standardization (ISO), Geneva, Switzerland.

Johnson, K. A., and D. E. Johnson. 1995. Methane emissions from cattle. J. Anim. Sci. 73:2483-2492.

Jones, G. A., T. A. McAllister, A. D. Muir, and K. J. Cheng. 1994. Effects of sainfoin (Onobrychis viciifolia Scop.) condensed tannins on growth and proteolysis by four strains of ruminal bacteria. Appl. Environ. Microbiol. 60:1374-1378.

Jung, H. G., and M. S. Allen. 1995. Characteristics of plant cell walls affecting intake and digestibility of forages by ruminants. J. Anim. Sci. 73:2774-2790

Livesey, G., and M. Elia. 1988. Estimation of energy expenditure, net carbohydrate utilization, and net fat oxidation and synthesis by indirect calorimetry: Evaluation of errors with special reference to the detailed composition of fuels. Am. J. Clin. Nutr. 47:608-628.

McMahon, L. R., W. Majak, T. A. McAllister, J. W. Hall, G. A. Jones, J. D. Popp, and K. J. Cheng. 1999. Effect of sainfoin on in vitro digestion of fresh alfalfa and bloat in steers. Can. J. Anim. Sci. 79:203-212.

Moyer, J. 1985. Effect of weed control and a companion crop on alfalfa and sainfoin establishment, yields and nutrient composition. Can. J. Plant Sci. 65:107-116.

Mueller-Harvey, I. 2006. Unravelling the conundrum of tannins in animal nutrition and health. J. Sci. Food Agric. 86:2010-2037.

Ominski, K., D. Boadi, and K. Wittenberg. 2006. Enteric methane emissions from backgrounded cattle consuming all-forage diets. Can. J. Anim. Sci. 86:393-400.
SAS Institute. 2010. SAS/STAT software. Version 9.3. SAS Institute Inc., Cary, NC.

Scharenberg, A., Y. Arrigo, A. Gutzwiller, U. Wyss, H. D. Hess, M. Kreuzer, and F. Dohme. 2007. Effect of feeding dehydrated and ensiled tanniferous sainfoin (Onobrychis viciifolia) on nitrogen and mineral digestion and metabolism of lambs. Arch. Anim. Nutr. 61:390-405.

Scharenberg, A., M. Kreuzer, and F. Dohme. 2009. Suitability of sainfoin (Onobrychis viciifolia) hay as a supplement to fresh grass in dairy cows. Asian-australas. J. Anim. Sci. 22:1005-1015.

Tavendale, M. H., L. P. Meagher, D. Pacheco, N. Walker, G. T. Attwood, and S. Sivakumaran. 2005. Methane production from in vitro rumen incubations with Lotus pedunculatus and Medicago sativa, and effects of extractable condensed tannin fractions on methanogenesis. Anim. Feed Sci. Technol. 123:403-419.

Van Duinkerken, G., M. C. Blok, A. Bannink, J. W. Cone, J. Dijkstra, A. M. Van Vuuren, and S. Tamminga. 2011. Update of the Dutch protein evaluation system for ruminants: The DVE/OEB2010 system. J. Agric. Sci. 149:351-367.

Van Es, A. 1975. Feed evaluation for dairy cows. Livest. Prod. Sci. 2:95-107.

van Gastelen, S., E. C. Antunes-Fernandes, K. A. Hettinga, G. Klop, S. J. J. Alferink, W. H. Hendriks, and J. Dijkstra. 2015. Enteric methane production, rumen volatile fatty acid concentrations, and milk fatty acid composition in lactating Holstein-Friesian cows fed grass silage- or corn silage-based diets. J. Dairy Sci. 98:1915-1927.

Van Soest, P. J. 1973. Collaborative study of acid-detergent fiber and lignin. J. Assoc. Off. Anal. Chem. 56:781-784.

Van Soest, P. J., J. B. Robertson, and B. A. Lewis. 1991. Methods for dietary fiber, neutral detergent fiber, and nonstarch polysaccharides in relation to animal nutrition. J. Dairy Sci. 74:3583-3597.

Waghorn, G. C. 2008. Beneficial and detrimental effects of dietary condensed tannins for sustainable sheep and goat productionProgress and challenges. Anim. Feed Sci. Technol. 147:116-139.

Waghorn, G. C., I. D. Shelton, and W. C. McNabb. 1994. Effects of condensed tannins in Lotus pedunculatus on its nutritive value for sheep. 1. Non-nitrogenous aspects. J. Agric. Sci. 123:99-107.

Waghorn, G. C., M. J. Ulyatt, A. John, and M. T. Fisher. 1987. The effect of condensed tannins on the site of digestion of amino acids and other nutrients in sheep fed on Lotus corniculatus L. Br. J. Nutr. 57:115-126.

Wang, Y., G. B. Douglas, G. C. Waghorn, T. N. Barry, and A. G. Foote. 1996a. Effect of condensed tannins in Lotus corniculatus upon lactation performance in ewes. J. Agric. Sci. 126:353-362.

Wang, Y., G. B. Douglas, G. C. Waghorn, T. N. Barry, A. G. Foote, and R. W. Purchas. 1996b. Effect of condensed tannins upon the performance of lambs grazing Lotus corniculatus and lucerne (Medicago sativa). J. Agric. Sci. 126:87-98.

Wang, Z., and L. A. Goonewardene. 2004. The use of MIXED models in the analysis of animal experiments with repeated measures data. Can. J. Anim. Sci. 84:1-11.

Warner, D., S. C. Podesta, B. Hatew, G. Klop, H. van Laar, A. Bannink, and J. Dijkstra. 2015. Effect of nitrogen fertilization rate and regrowth interval of grass herbage on methane emission of zerograzing lactating dairy cows. J. Dairy Sci. 98:3383-3393.

Williams, A. R., C. Fryganas, A. Ramsay, I. Mueller-Harvey, and S. M. Thamsborg. 2014. Direct anthelmintic effects of condensed tannins from diverse plant sources against Ascaris suum. PLoS ONE 9:e97053.

Wood, J. G. M., and J. Parker. 1971. Respiration during the drying of hay. J. Agric. Eng. Res. 16:179-191.

Woodward, S. L., P. G. Laboyrie, and E. B. L. Jansen. 2000. Lotus corniculatus and condensed tannins-effects on milk production by dairy cows. Asian-australas. J. Anim. Sci. 13:521-525.

Woodward, S. L., G. C. Waghorn, K. R. Lassey, and P. G. Laboyrie. 2002. Does feeding sulla (Hedysarum coronarium) reduce methane emissions from dairy cows? Proc. N.Z. Soc. Anim. Prod. 62:227230 